Pak. j. sci. ind. res. Ser. A: phys. sci. 201356 (3) 176-179

\title{
Determination of Physicochemical Parameters of Sugar Mill Effluents
}

\author{
Aftab Ahmed Kandhro ${ }^{a *}$, Razia Begam ${ }^{a}$, Aijaz Panhwar ${ }^{b}$, Tooba Haq ${ }^{\text {, }}$ \\ Niaz Ahmed ${ }^{\mathrm{a}}$ and Alia Bano ${ }^{\mathrm{a}}$ \\ aPCSIR Laboratories Complex, Karachi-75280, Pakistan \\ bPSQCA, Block-77, Pakistan Secretariat, Saddar, Karachi, Pakistan \\ (received February 27, 2012; revised July 9, 2012; accepted July 31, 2012)
}

\begin{abstract}
A study on the determination of physicochemical parameters of sugar mills effluents has been carried out. In this scenario samples were taken from various parts of mills including mill house, process house, spray pond, compositive main drain colony and compositive main drain after lagoon. These samples were then subjected to analysis of some important physicochemical parameters such as $\mathrm{pH}$, total dissolve solids (TDS), total suspended solids (TSS), biochemical oxygen demand (BOD), chemical oxygen demand (COD) and oil and grease. The results of all the effluent samples show that values of all the parameters are above the range fixed by national environmental quality standards (NEQS).
\end{abstract}

Keywords: sugar mill effluent, physicochemical parameters, environmental quality standards

\section{Introduction}

The sugar industry of Pakistan is considered to be one of the best organized in the industrial sector of the country and also among the country's leading economic enterprises (Bailley, 1999). It comprises of 77 mills, 38 in the province of Punjab, 32 in Sindh, 6 in the Khyber Pakhtunkhwa, and one in Azad Jammu and Kashmir (PSMA, 2004). Almost the entirety of the sugar output is used domestically while molasses (by-product of sugar production) is mostly exported. A few sugar mills also use part of the molasses to produce industrial alcohol (ethyl alcohol), a significant quantity of which is also exported (PSMA, 2004).

Sugar industry plays an important role in the economy of countries by export of the sugar and by-products obtained from the processing of sugarcane as well as by farming and creation of employment. The by-products of sugar mills are also used as raw materials in different industries. However, effluents, especially liquid effluents emanating from sugar mills have a great environmental impact upon the surrounding environment. The change of water chemistry is the main environmental impact of the indiscriminate discharge of sugar mill effluent in an open water body. The effluents cause irritant odour during their decomposition. Wastewater from sugar mills with its high BOD and COD rapidly deplete the available oxygen supply when discharged into water bodies. These effluents endanger aquatic life and also

$\overline{\text { *Author for correspondence; E-mail: chemist_afi@yahoo.com }}$ create unhygienic septic conditions, generating foulsmelling hydrogen sulphide, which in turn may precipitate iron and any dissolved salts, turning the water black and highly toxic for aquatic life (Salequzzaman et al., 2008).

Fast urbanization and industrialization in the developing countries like Pakistan poses severe problems in the collection, treatment and disposal of obnoxious effluents. This situation leads to serious public health problems. Unmanaged organic waste generated from industries, municipalities and the agricultural sector decomposes, thereafter resulting in the large scale contamination of land, water and air in the environment (Hampannavar and Shivayogimath, 2010). These wastes not only represent a threat to the quality of environment but also possess a potential energy value which is not fully utilized despite the fact that they are cheap and abundant in most parts of the world.

Rapid increase of industrialization trend in the world has resulted in the generation of industrial effluents in quite large quantities with high organic content, which if treated/processed appropriately, may become a significant source of energy.

The problem of environmental pollution on account of fast industrial growth is mainly due to the indiscriminate disposal of industrial waste solid, liquid or gases. Polluted water, in addition to other effects, directly affects the soil not only in the industrial areas but also in the agricultural fields and river beds, thereby creating 
secondary source of pollution and endangering the food chain (Barman et al., 2000; Kisku et al., 2000). Different industries have been continuously adding to a large amount of wastewater, containing high level of nutrients, heavy metals and hazardous substances to the agrarian land (Malaviya and Rathore, 2007; Chandra et al., 2004; Srivastava et al., 2000). These effluents not only increase the nutrient level, but also multiply the tolerance limits and hence causes potent toxicity (Mishra et al., 1999).

Sugar industry is basically seasonal and operates only for 120-180 days in a year (November to April). A significantly large volume of waste is generated during the manufacturing of sugar and contains high amount of pollutants, particularly in terms of liquid effluent, organic matter, press mud bagasse and air pollution. Liquid effluents generated by sugar industries comprise a number of constituents, including suspended and dissolved solids. Further these effluents have high amount of BOD, COD, chlorides, sulphates, nitrates, calcium and magnesium. The highly polluted wastewater from sugar mills, in particular, poses a substantial danger to health and environment. In the past physicochemical characteristics of industrial effluents as well as their impact on plants and animals have been extensively worked out (Kumar and Gopal, 2001; Mishra et al., 1999). The spatial variations in the geochemical characteristics of groundwater appear to be related to pollution due to effluents from the sugar mills. The aim of this study was to determine the various physicochemical parameters of sugar and distillery (mixed treated) effluents and their possible after effects on the surrounding environment.

\section{Materials and Methods}

Sampling and reagents. Effluent samples were collected from four sugar mills located in the province of Sindh, during an industrial survey. Standard protocols/procedures were used for the collection, transportation, storage and chemical analysis of the samples. Samples were collected in the air tight sampling bottles and placed in an ice box to preserve the inherent characteristics of the effluents. All the reagents, chemicals and solvents used in this study were purchased from Merck (Darmstadt, Germany).

Determination of temperature, pH, TDS, COD, BOD, oils and grease. Various physicochemical parameters (temperature, $\mathrm{pH}, \mathrm{TSS}, \mathrm{TDS}, \mathrm{COD}, \mathrm{BOD}$, oils and grease) of the samples of liquid effluents have been analysed by using standard methods for the examination of water and wastewater (AWWA/APHA, 2005).

\section{Results and Discussion}

In the present study, sampling of liquid effluent samples were done from different sugar mills in the province of Sindh and these samples were thereafter, examined for their $\mathrm{pH}$, temperature, TSS, TDS, BOD, COD, oil and grease content. Table 1 presents the analysed results of sugar mill effluents comparison with discharge quality standards, National Environmental Quality Standards (NEQS) limits.

Figure 1 shows a comparison of the pollutants levels of each parameter of the effluents among the designated four sampling points from sugar mills. While, the results of different physicochemical parameters are given in Table 2. The average temperature has been found to be around the maximum permissible temperature, while the $\mathrm{pH}$ value fell within the acceptable range (Table 1). Among the physicochemical parameters, only temperature and $\mathrm{pH}$ have been found to be within the standard range while all other parameters such as TDS, TSS, COD, BOD, oil and grease deviate and generally fall in the higher range when compared to standard NEQS values. The four different main sampling points were selected in mill, i.e., mill house, process house, main draincolony and main drain-lagoon. The effluents emanating

Table 1. Sugar mill effluents compared with waste discharge quality standards

\begin{tabular}{llll}
\hline \hline Parameters & *Standards & Mill house effluent & Remarks \\
\hline Temperature $\left({ }^{\circ} \mathrm{C}\right)$ & 40 & $7.5-8.2$ & within the standard \\
$\mathrm{pH}$ & $6-10$ & $35-40$ & maintain the standard \\
TDS $(\mathrm{mg} / \mathrm{g})$ & $0.48-1.28$ & 3.11 & doesn't maintain the standard \\
TSS $(\mathrm{mg} / \mathrm{g})$ & 0.15 & 0.242 & doesn't maintain the standard \\
$\mathrm{COD}(\mathrm{mg} / \mathrm{g})$ & 0.15 & 0.82 & doesn't maintain the standard \\
BOD $(\mathrm{mg} / \mathrm{g})$ & 0.08 & 0.22 & much grater than the standard \\
Oil and grease $(\mathrm{mg} / \mathrm{g})$ & 0.01 & 0.268 & much grater than the standard \\
\hline \hline
\end{tabular}

* = National Environmental Quality Standards (NEQS) limits. 


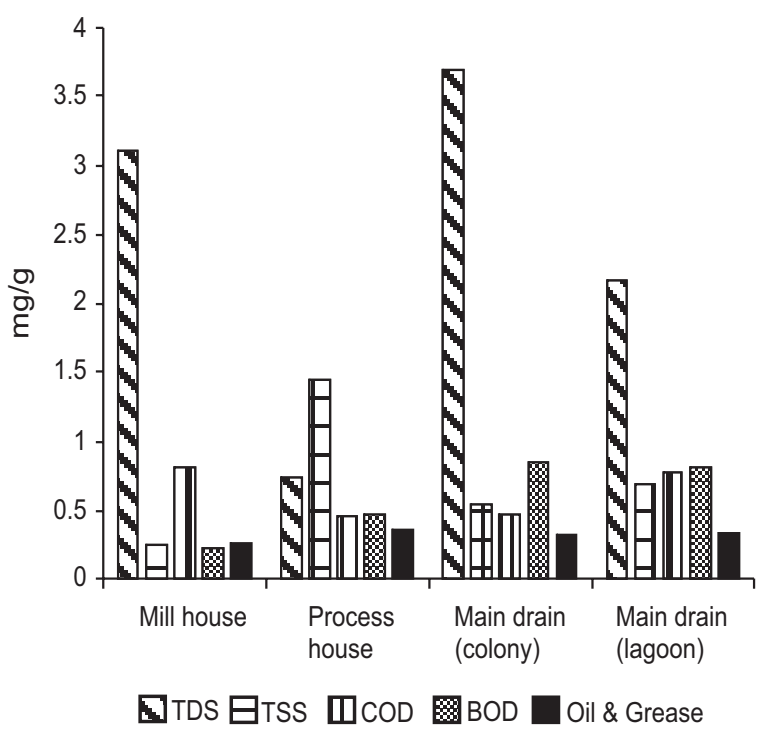

Fig. 1. Comparison of different physicochemical parameters collected from four effluents points of sugar mill.

from these points were thereafter subjected to the determi-nation of different physicochemical characteristics or quality parameters. The samples were collected during the summer months and that's why all the samples have around the same temperature range $\left(35-40{ }^{\circ} \mathrm{C}\right)$ from all the four sampling points, while the $\mathrm{pH}$ ranged between 7.5-8.2, 4.6-5.1, 7.7-8.1 and 8.4-9.2 for mill house, process house, main drain-colony and main drain-lagoon, respectively.

Discharge of water with a higher TDS value may have an adverse effect on the aquatic life (Salequzzaman et al., 2008), and render the water unfit for drinking and domestic purpose, reduce crop yield if used in irrigation, and exacerbate corrosion in pipeline used in water supply system (ETPI, 2001). TDS values for the mill house, process house, main drain-colony and main drain-lagoon were at $3.11,0.73,3.70$ and $2.17 \mathrm{mg} / \mathrm{g}$, respectively, while the highest value were determined in main drain-colony $(3.70 \mathrm{mg} / \mathrm{g})$.

TSS generally reduces the light penetration capability and, as a result, plant life in the receiving water body is gradually diminishing through increased turbidity. Further, these may also clog the fish gills (Salequzzaman et al., 2008). TSS value determined at $0.242,1.442$, 0.544 and $0.686 \mathrm{mg} / \mathrm{g}$ were found in the samples collected from four sample collecting sites. The data presented in the study shows that wastewater with varying load of pollution is generated at nearly all the stages of sugar production. Cane washing generate waste water that has a high concentration of suspended solids and may have a significant sugar concentration due to the damage incurred by the cane during mechanical harvesting.

The higher values of COD in the effluent samples reveal the presence of high concentration of biodegradable organic matter in the effluent (Kumar and Gopal, 2001). Higher COD value is a measure of the inorganic and partly organic non-biodegradable content of the effluents and has after effects on the receiving water body similar to that of a higher BOD effluent. Wastewater from sugar mills with its high BOD rapidly depletes available oxygen supply and these effluents when discharged into water bodies endanger the fish and other aquatic life. The high BOD also creates septic and unhygienic conditions, generating foul-smelling hydrogen sulphide, which in turn may precipitate iron and any dissolved salts, turning the water black and highly toxic for aquatic life. The liquid and gaseous effluents produced from the sugar industry have quite an adverse impact on the ecosystem and our environment due to their high BOD load and toxic constituents (Solomon, 2005). The determined values of COD are $0.82,0.46,0.475$ and $0.778 \mathrm{mg} / \mathrm{g}$; and BOD are $0.22,0.47,0.845$ and $0.82 \mathrm{mg} / \mathrm{g}$, in four sampling points while the pattern of oil and grease content in the four effluent samples have

Table 2. Physicochemical characteristics of different effluent points of sugar mill

\begin{tabular}{lllll}
\hline \hline Parameters & Mill house & Process house & Main drain (colony) & Main drain (lagoon) \\
\hline $\mathrm{pH}$ & $7.5-8.2$ & $4.6-5.1$ & $7.7-8.1$ & $8.4-9.2$ \\
Temperature $\left({ }^{\circ} \mathrm{C}\right)$ & $35-40$ & $35-40$ & $35-40$ & $35-40$ \\
TDS $(\mathrm{mg} / \mathrm{g})$ & $3.11 \pm 0.05$ & $0.73 \pm 0.02$ & $3.7 \pm 0.13$ & $2.17 \pm 0.05$ \\
TSS $(\mathrm{mg} / \mathrm{g})$ & $0.242 \pm 0.01$ & $1.442 \pm 0.03$ & $0.544 \pm 0.02$ & $0.686 \pm 0.02$ \\
COD $(\mathrm{mg} / \mathrm{g})$ & $0.82 \pm 0.01$ & $0.46 \pm 0.01$ & $0.475 \pm 0.02$ & $0.778 \pm 0.03$ \\
BOD $(\mathrm{mg} / \mathrm{g})$ & $0.22 \pm 0.01$ & $0.47 \pm 0.01$ & $0.845 \pm 0.02$ & $0.82 \pm 0.02$ \\
Oil \& grease $(\mathrm{mg} / \mathrm{g})$ & $0.268 \pm 0.01$ & $0.356 \pm 0.01$ & $0.314 \pm 0.01$ & $0.326 \pm 0.01$ \\
\hline \hline
\end{tabular}


found to be at $0.268,0.356,0.314$ and $0.326 \mathrm{mg} / \mathrm{g}$, for mill house, process house, main drain (colony) and main drain (Lagoon), respectively.

\section{Conclusion}

It has been concluded from the studies that all analysed effluent samples from different points of sugar mills have quite higher content of TDS, TSS, COD, BOD and oils and grease as per NEQS. In order to protect the water resources from these hazardous liquid wastes, it is recommended that environmental protection agency (EPA) of respective provinces should make it mandatory for sugar mills to pretreat the liquid effluents before their discharge in the water body/sewer.

\section{References}

AWWA/APHA, 2005. Standard Methods for the Examination of Water and Wastewater, AWWA-APHAWEF, $21^{\text {st }}$ edition, Washington, DC., USA.

Barman, S.C., Sahu, R.K., Bhargava, S.K., Chatterjee, C. 2000. Distribution of heavy metals in wheat, and mustard grown in field irrigated with industrial effluent. Bulletin of Environmental Contamination and Toxicology, 64: 489-496.

Bailley, H. 1999. Pollution Prevention and In-Plant Control Measures in Sugar Mills - A Guidebook for Technical and Operational Staff. Islamabad: Sustainable Development Policy Institute (SDPI), Pakistan.

Chandra, R., Kumar, K., Singh, J. 2004. Impact of anaerobically treated and untreated (raw) distillery effluent irrigation on soil microflora, growth, total chlorophyll and protein contents of Phaseolus aureus L. Journal of Environmental Biology, 25: 381-385.

ETPI. 2001. Environmental Technology Program for Industry. Environmental Report on Sugar Sector. Monthly Environmental News, 5: 11-27.

Hampannavar, U.S., Shivayogimath, C.B. 2010. An aerobic treatment of sugar industry wastewater by upflow anaerobic sludge blanket reactor at ambient temperature. International Journal of Environmental Sciences, 1: 631-639.

Kisku, G.C., Barman, S.C., Bhargava, S.K. 2000. Contamination of soil and plants potentially toxic elements irrigated with mixed industrial effluent and impact in the environment. Water, Air \& Soil Pollution, 120: 121-137.

Kumar, S., Gopal, K. 2001. Impact of distillery effluent on physiological consequences in the fresh water teleost, Channa punctatus. Bulletin of Environmental Contamination and Toxicology, 66: $617-$ 622.

Malaviya, P., Rathore, V.S. 2007. Seasonal variation in different physicochemical parameters of the effluent of century pulp and paper mill, Lal Kuan, Uttrakhand. Journal of Environmental Biology, 28: 219-224.

Mishra, S., Tiwari, T.N., Mishra, P.C. 1999. Bioaccumulation and bioconcentration of metals in water and sediment of river Brahmani at Rourkela. In: Modern Trends in Environmental Pollution and Ecoplanning, A. Kumar (ed.), pp. 21-81, ABD Publication, Jaipur, India.

PSMA, 2004. Pakistan Sugar Mills Association. Islamabad: (Accessed July 7, 2011, 4, 2005: http:// www. psmaonline.com/psma/annual/annual_report/ psmaar2004.pdf)

Salequzzaman, M., Tariqul-Islam, S.M., Tasnuva, A., Kashem, M.A., Mahedi Al Masud, M. 2008. Environmental impact of sugar industry - A case study on Kushtia Sugar Mills in Bangladesh. Journal of Innovation and Development Strategy, 2: 31-35.

Solomon, S. 2005. Environmental pollution and its management in sugar industry in India: An appraisal. Sugar Technology, 7: 77-81.

Srivastava, P.K., Pandey, G.C., Naraliya, S. 2000. Bioaccumulation of distillery effluent metals by some aquatic macrophytes. Proceedings of the Indian National Science Academy India, 70: 311-318. 